\title{
IN VITRO SCREENING OF ANTIOXIDANT AND ANTIAGING POTENTIAL OF CUCUMIS SATIVUS FRUIT EXTRACT
}

\author{
CHANCHAL GARG, RAVINDER SINGH, MUNISH GARG*
}

Department of Pharmaceutical Sciences, Maharshi Dayanand University Rohtak, Haryana, India. Email: mgarg2006@gmail.com

Received: 05 March 2020, Revised and Accepted: 04 April 2020

ABSTRACT

Objective: The present study was designed to screen the anti-aging and anti-wrinkle potential of Cucumis sativus fruit through in vitro estimation of antioxidant, anti-hyaluronidase, anti-elastase, anti-collagenase/anti-matrix metalloproteinase (MMP)-1, and anti-tyrosinase activity.

Methods: Raw juice of cucumber was taken, filtered and fractionated with ethyl acetate and n-butanol. The obtained extracts were then evaluated for their antioxidant potential through 1, 1-diphenyl-2-picryl-hydrazyl (DPPH) radical scavenging assay taking ascorbic acid as positive control and other enzymatic activities in reference to hyaluronidase inhibition, MMP-1/collagenase inhibition, and elastase inhibition taking catechin as reference standard whereas for tyrosinase inhibition the standard used was quercetin.

Results: All the evaluations were performed in triplicates and results were noted down. It was observed that aqueous extract of $C$. sativus fruits showed a maximum DPPH radical scavenging activity $(\mathrm{p}<0.0001)$, half-maximal inhibitory concentration $\left(\right.$ IC $\mathrm{C}_{50}$ ) at a concentration of $122.67 \mu \mathrm{g} / \mathrm{ml}$. The ethyl acetate fraction of $C$. sativus fruits exhibited maximum hyaluronidase $(\mathrm{p}<0.0001)$, MMP-1/collagenase ( $<<0.04$ ), and tyrosinase ( $<0.04$ ) inhibitory activity, $\mathrm{IC}_{50}$ at a concentration of $59.54,45.79$, and $24.46 \mu \mathrm{g} / \mathrm{ml}$, respectively. The elastase $(\mathrm{p}<0.0001)$ inhibitory activity by $\mathrm{n}$-butanol fraction of $C$. sativus fruits extract was maximum, $\mathrm{IC}_{50}$ at a concentration of $52.76 \mu \mathrm{g} / \mathrm{ml}$.

Conclusion: A potent anti-aging and anti-wrinkle properties were well demonstrated by $C$. sativus, as depicted from the results obtained.

Keywords: Anti-aging, Anti-wrinkle, Cucumis sativus, Antioxidant, Hyaluronidase, Elastase, Matrix metalloproteinase-1, Tyrosinase.

(C) 2020 The Authors. Published by Innovare Academic Sciences Pvt Ltd. This is an open access article under the CC BY license (http://creativecommons. org/licenses/by/4. 0/) DOI: http://dx.doi.org/10.22159/ajpcr.2020.v13i5.37358

\section{INTRODUCTION}

Aging is a progressive process influenced by both intrinsic and chronological factors and extrinsic or environmental factors which include ultraviolet (UV) rays, air pollution, stress, or smoking [1]. Excessive exposure to UV rays results in the formation of reactive oxygen species (ROS) which causes the adverse effects on the dermal and epidermal connective tissues leading to the damage to cell and cell membranes [2]. Skin physiological changes occurring due to the acceleration of the free radicals, cell contents, and lipid peroxidation stimulated by high exposure to UV radiation directly cause skin aging [3]. Skin shows rugged appearance, hyperpigmentation, dark spots, deep wrinkles, etc. [4]. Hyaluronic acid, elastin, and collagen are important for maintaining skin structure, moisture content, elasticity, and strength of connective tissue of the skin which is decreased in the aging skin [5-7]. The increase in the activity of hyaluronidase, elastase, and collagenase/matrix metalloproteinase (MMP)-1 is responsible for decrease in the strength of connective tissue, water holding capacity of the skin, and elasticity of skin. Excessive exposure to UV radiations also results in the development of dark spots which may be due to the overproduction of melanin [8]. Tyrosinase is the main enzyme that catalysis melanin synthesis in melanocytes [9]. Inhibition of these enzymes plays an important role in skin aging. Since traditional medicines and plants provide an extensively large unexplored source for the development of new, potent, and safe cosmetic and skincare products, researchers have paid attention on the exploration of plants and plant extracts for combating skin aging [2]. In the present study, Cucumis sativus commonly known as cucumber was studied for its antiaging and anti-wrinkle potential. It is a commonly used vegetable crop which belongs to the Cucurbitaceae family [10]. Conventionally, it has been used widely for various skin problems and applied topically for swollen eyes, burns, dermatitis, antioxidant, skin whitening and antiwrinkle effect, analgesic, anticancer, and hypoglycemic activity $[11,12]$.
Chemical composition of cucumber fruit includes $\alpha$-linolenic acid, Caffeic acid, Citrulline, Vitamin C, Cucurbitin B, $\beta$ amyrin, $\beta$ sitosterol, Chlorogenic acid, Cucurbitin A, Cucurbitin C, Cucurbitin E, Ferulic acid, Folacin, Hexanal, Pentadec-cis-8-en-1-al, Mevalonic acid, Rubidium, Strontium, $\gamma$-glutamyl-beta-pyrazole-1-yl-alanine, Hexen-(2)-al-(1), Propanal, Myristic acid, Squalene, and Zirconium [13]. Taking into accounts the above aspects, the present study was designed to evaluate the anti-aging and anti-wrinkle potential of $C$. sativus fruit juice.

\section{METHODS}

Collection and authentication of plant materials

The fruits of $C$. sativus were collected from the local market of Rohtak in the month of October-November 2017 and authenticated from the Department of Botany Maharshi Dayanand University, Rohtak. The voucher specimen (VS/Ph $\operatorname{cog} / 2017 / 401$ ) of C. sativus is kept in the Department of Pharmaceutical Sciences, Maharshi Dayanand University, Rohtak.

\section{Chemicals}

1, 1-diphenyl-2-picryl-hydrazyl (DPPH), Tris-HCL buffer, Tricine buffer, Catechin, Tris-HCL buffer, Bovine Hyaluronidase enzyme, Collagenase from Clostridium histolyticum, porcine pancreatic elastase, FurylacryloylLeucine-Glycine-Propyl-Alanine (FALGPA), N-(methoxysuccinyl)-alaala-pro-val 4-nitroanilide (MAAPVN), Albumin, Tyrosinase, Sodium hyaluronate, acetate buffer, dimethyl sulfoxide (DMSO), calcium chloride, and p-dimethyl amino benzaldehyde (PDMAB) were procured from Sigma Aldrich and Fluka chemicals. Other chemicals and reagents were of analytical grade which was used in the present evaluation.

\section{Extraction and fractionation of plant material}

Two kilograms fruits of $C$. sativus were taken and washed properly. Then peeled off and seeds were removed and juice was collected 
in juicer. The juice of fruits was fractionated with ethyl acetate and n-butanol $(150 \mathrm{ml}$ each) and separated the resultant portions using separating funnel and aqueous portion left in the funnel. The obtained fractions were evaporated and concentrated to get the respective extracts. The extractive values of all the fractions are depicted in Table 1.

\section{Antioxidant studies}

DPPH radical scavenging activity

The antioxidant potential of the extract was based on the inhibitory potential of the stable DPPH free radical and the procedure followed was as explained by Braca et al. [14] with little changes. The extracts of C. sativus were prepared in a dilution series $(100,200$, and $300 \mu \mathrm{g} / \mathrm{ml})$ in DMSO. The reaction mixture consisted of $0.1 \mathrm{~mL}$ test sample with $0.2 \mathrm{~mL}$ DPPH solution $(0.15 \mathrm{mM}$ in $80 \%$ methanol solution). The final reaction mixture was shaken dynamically and kept at room temperature for $30 \mathrm{~min}$ in the dark. Ascorbic acid was used as a standard. The evaluations were done spectrophotometrically (using ELISA reader) at $517 \mathrm{~nm}$ and the \% scavenging potential was calculated by the given formula:

Inhibitory activity $(\%)=($ Abs control - Abs sample $\backslash$ Abs control $) \times 100$.

Where Abs is the absorbance

The antioxidant potential of the extracts was demonstrated as halfmaximal inhibitory concentration $\left(\mathrm{IC}_{50}\right)$ (a concentration $[\mu \mathrm{g} / \mathrm{ml}]$ which $50 \%$ reduction in the formation of DPPH free radicals are known as $\mathrm{IC}_{50}$ value of any drug or plant extract). All the observations were taken in the triplicates, graph was plotted by average.

\section{Enzymatic studies}

Hyaluronidase inhibitory activity

Fifty microliter bovine hyaluronidase (prepared by diffusing 7900 units $/ \mathrm{ml}$ of enzyme in $0.1 \mathrm{M}$ acetate buffer; $\mathrm{pH} 3.5$ ) was added to $50 \mu \mathrm{l}$ of different dilutions of test extract prepared using 5\% DMSO and incubated at $37^{\circ} \mathrm{C}$ for $20 \mathrm{~min}$. In the control group, $50 \mu \mathrm{l}$ of DMSO was added instead of plant extract. Hyaluronidase was activated by the addition of $50 \mu \mathrm{l}$ of calcium chloride $(12.5 \mathrm{mM})$ in reaction mixture and the whole mixture was incubated for $20 \mathrm{~min}$ at $37^{\circ} \mathrm{C}$. The obtained $\mathrm{Ca}+2$ activated hyaluronidase was then treated with $250 \mu \mathrm{l}$ of sodium hyaluronate $(0.1 \mathrm{M}$ acetate buffer; $\mathrm{pH} 3.5$, was used to diffuse $1.2 \mathrm{mg} / \mathrm{ml}$ ) and kept for $3 \mathrm{~min}$ on a water bath at $100^{\circ} \mathrm{C}$. The reaction mixture was then cooled to room temperature and added $1.5 \mathrm{ml}$ of PDMAB ([4 g] dissolved in glacial acetic acid [350 ml] and 10 $\mathrm{N} \mathrm{HCl}[50 \mathrm{ml}]$ ). The reaction mixture was then kept for $20 \mathrm{~min}$ at room temperature [15]. The absorbance was measured at $585 \mathrm{~nm}$. Inhibitory effect was calculated as:

Inhibition $(\%)=([$ Abs of control-Abs of sample $] /$ Abs of control $) \times 100$

Abs $=$ Absorbance

\section{MMP-1/Collagenase inhibitory activity}

MMP-1/collagenase inhibition assay was carried out on the basis of the method discussed by Kim et al. [16] It involves the use of collagenase ( 0.8 units $/ \mathrm{ml}$ ) from $C$. histolyticum and $2 \mathrm{mM}$ of synthetic substrate, FALGPA. The final reaction mixture contained $25 \mu \mathrm{l}$ of $50 \mathrm{mM}$ tricine buffer, $25 \mu \mathrm{l}$ of the test sample, and $25 \mu \mathrm{l}$ of collagenase enzyme ( 0.1 units). After the addition of $50 \mu \mathrm{l}$ of $2 \mathrm{mM}$ FALGPA, absorbance was

Table 1: \% yield obtained for different extracts of Cucumis sativus

\begin{tabular}{lll}
\hline S. No & Extracts & Extractive value $(\% \mathbf{W} / \mathbf{W})$ \\
\hline 1. & Ethyl acetate & 0.035 \\
2. & n-butanol & 0.085 \\
3. & Water & 1.35 \\
\hline
\end{tabular}

immediately measured at $340 \mathrm{~nm}$ by ELISA reader. Catechin was used as a standard. The $\%$ enzyme inhibition was calculated by the given formula:

Enzyme inhibition activity $(\%)=(1-[\mathrm{B} / \mathrm{A}]) \times 100$

Where $\mathrm{A}=$ activity of control, $\mathrm{B}=$ activity of test extracts.

Elastase inhibitory activity

Elastase inhibition activity was analyzed by the procedure discussed by Pientaweeratch et al. [17] Mix $0.1 \mathrm{ml}$ of a $0.2 \mathrm{M}$ Tris- $\mathrm{HCl}$ buffer having $1 \%$ albumin, $0.025 \mathrm{ml}$ of $10 \mathrm{mM}$ MAAPVN and $0.05 \mathrm{ml}$ of the sample of different concentrations $(20 \mu \mathrm{g} / \mathrm{ml}$, $40 \mu \mathrm{g} / \mathrm{ml}, 60 \mu \mathrm{g} / \mathrm{ml}, 80 \mu \mathrm{g} / \mathrm{ml}$, and $100 \mu \mathrm{g} / \mathrm{ml}$ ). Then add $0.025 \mathrm{ml}$ of elastase (3 units $/ \mathrm{ml}$ ) to each test sample. Incubate the resultant reaction mixture at $25^{\circ} \mathrm{C}$ for $20 \mathrm{~min}$ and measure the absorbance by ELISA reader at $410 \mathrm{~nm}$. Percentage inhibition was calculated using following formula:

Inhibition rate $(\%)=(1-[C-D] /[A-B]) \times 100$

Where,

A and B represent the absorbance without a test sample after and before incubation, respectively,

$\mathrm{C}$ and $\mathrm{D}$ represent the absorbance with a test sample after and before incubation, respectively.

\section{Tyrosinase inhibitory activity}

The determination of tyrosinase was performed using L-DOPA as substrate [18-21]. First, dissolve $0.8 \mathrm{ml}$ of L-DOPA $(2.5 \mathrm{mM})$ with $2.4 \mathrm{ml}$ of phosphate buffer solution $(0.067 \mathrm{M})$ of $\mathrm{pH} 6.6$. Then incubate the reaction mixture for $10 \mathrm{~min}$ at $37 \mathrm{sC}$. After this, $0.8 \mathrm{ml}$ of $2 \mathrm{mg} / \mathrm{ml}$ extracts and $0.8 \mathrm{ml}$ tyrosinase solution were mixed. The solution was instantaneously examined for the generation of dopachrome by estimating the linear rise in optical density for $5 \mathrm{~min}$ at $475 \mathrm{~nm}$. The observations were taken in triplicates. The tyrosinase inhibitory activity was estimated by the formula:

$$
\text { Inhibition }(\%)=\frac{(\mathrm{C}-\mathrm{D})(\mathrm{A}-\mathrm{D})}{\mathrm{C}-\mathrm{D}}
$$

Where, A and B are the absorbance of a sample with L-DOPA and without L-DOPA, respectively,

C is the absorbance without sample and with substrate, and D is the absorbance without both sample and substrate.

\section{Statistical analysis}

Data are expressed as $\mathrm{IC}_{50}$. Linear regression was used to determine the $\mathrm{IC}_{50}$ values.

\section{RESULTS}

\section{Determination of extractive value}

In the present study, the fruits of $C$. sativus were collected and juice was prepared followed by fractionation using ethyl acetate and n-butanol. The extracts were dried; stored and extractive value was evaluated. The results are summarized in Table 1.

\section{In vitro DPPH radical scavenging activity}

The absorbance of all extracts was measured at $517 \mathrm{~nm}$ for different concentrations. The percentage antioxidant activity of ethyl acetate, $\mathrm{N}$-butanol, and aqueous extract of $C$. sativus at $300 \mu \mathrm{g} / \mathrm{ml}$ exhibited the maximum antioxidant potential of $47.13,49.64$, and $72.40 \mu \mathrm{g} / \mathrm{ml}$, respectively, while ascorbic acid at $300 \mu \mathrm{g} / \mathrm{ml}$ concentration exhibited the antioxidant potential of 91.11. C. sativus extracts (ethyl acetate, $\mathrm{N}$-butanol, and aqueous) have dose-dependent significant ( $\mathrm{p}<0.0001)$ DPPH radical inhibitory activity with $\mathrm{IC}_{50}$ value, at a concentration of $358.04,294.64$, and $122.67 \mu \mathrm{g} / \mathrm{ml}$, respectively, in comparison to ascorbic acid ( IC $_{50}$ ) at $24.57 \mu \mathrm{g} / \mathrm{ml}$. Fig. 1 shows the DPPH radical inhibitory potential of $C$. sativus extracts as compared to ascorbic acid. 
Hyaluronidase inhibitory activity

The absorbance of all extracts was read at $585 \mathrm{~nm}$ for different concentrations and the percentage of the total anti-hyaluronidase potential of ethyl acetate, n-butanol, and aqueous extracts of $C$. sativus was calculated. The ethyl acetate, n-butanol, and aqueous extracts of $C$. sativus at $100 \mu \mathrm{g} / \mathrm{ml}$ exhibited a maximum total hyaluronidase inhibition (Fig. 2) of 58.73, 88.59, and 59.15. The $\mathrm{IC}_{50}$ value of the ethyl acetate $(59.54 \mu \mathrm{g} / \mathrm{ml}), \mathrm{n}$-butanol $(377.28 \mu \mathrm{g} / \mathrm{ml})$, and aqueous extracts $(75.84 \mu \mathrm{g} / \mathrm{ml})$ of $C$. sativus was found to be significant $(\mathrm{p}<0.0001)$, as compared to standard catechin having the $\mathrm{IC}_{50}$ value of $14.57 \mu \mathrm{g} / \mathrm{ml}$.

\section{Elastase inhibitory activity}

The absorbance of all extracts was read at $410 \mathrm{~nm}$ for different concentrations and the percentage of total anti-elastase potential

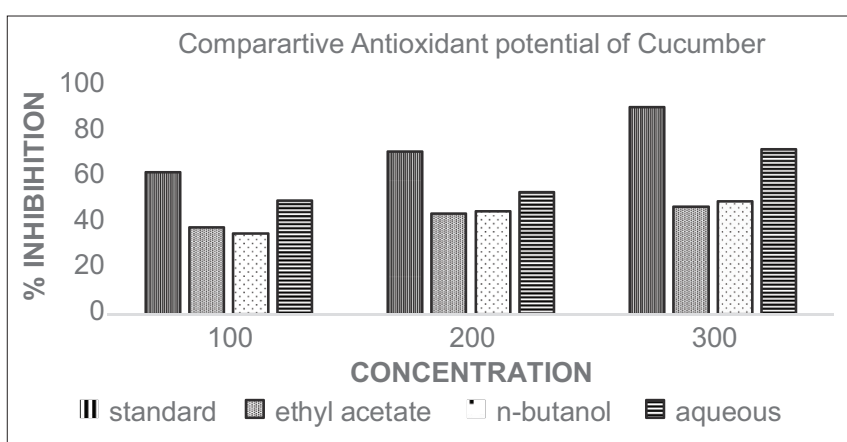

Fig. 1: 1, 1-diphenyl-2-picryl-hydrazyl radical inhibitory potential of Cucumis sativus extracts to compare with ascorbic acid. All values were found to be significant $(p<0.0001)$

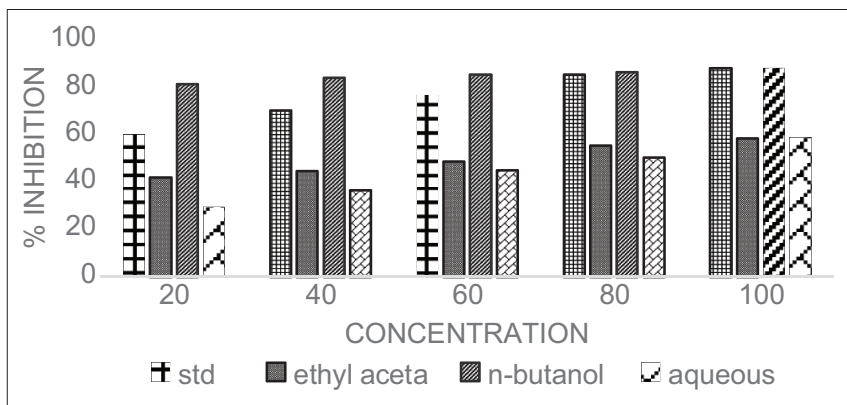

Fig. 2: Hyaluronidase inhibitory potential of Cucumis sativus extracts to compare with catechin. All values were found to be significant $(p<0.0001)$

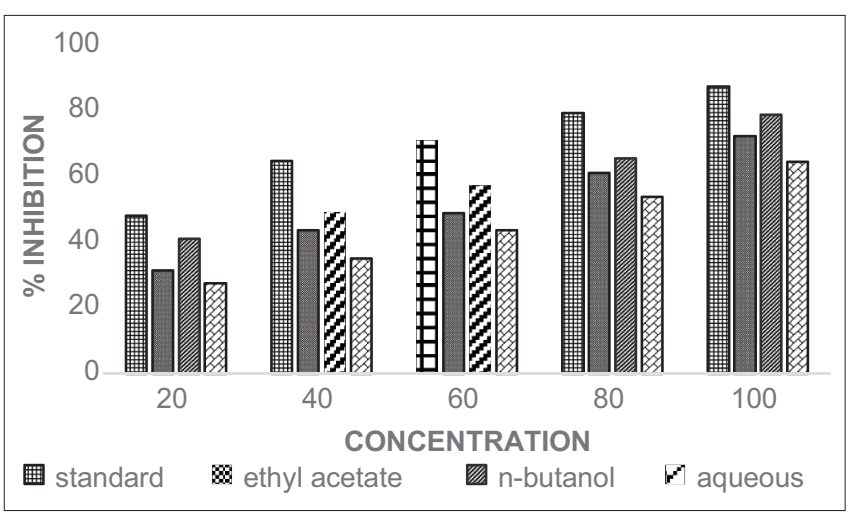

Fig. 3: Elastase inhibitory potential of Cucumis sativus extracts to compare with catechin. All values were found to be significant $(\mathrm{p}<0.03)$ of ethyl acetate, n-butanol, and aqueous extracts of $C$. sativus was calculated. The ethyl acetate, n-butanol, and aqueous extracts of C. sativus at $100 \mu \mathrm{g} / \mathrm{ml}$ exhibited a maximum total elastase inhibition (Fig. 3) of 71.54, 76.98, and $67.80 \mu \mathrm{g} / \mathrm{ml}$, respectively. The $\mathrm{IC}_{50}$ value of the ethyl acetate $(52.76 \mu \mathrm{g} / \mathrm{ml}), \mathrm{n}$-butanol $(42.16 \mu \mathrm{g} / \mathrm{ml})$, and aqueous $(66.08 \mu \mathrm{g} / \mathrm{ml})$ extracts of $C$. sativus was found to be significant $(\mathrm{p}<0.03)$ in comparison to standard catechin having the $\mathrm{IC}_{50}$ value $1.84 \mu \mathrm{g} / \mathrm{ml}$.

\section{MMP-1/Collagenase inhibitory activity}

The absorbance of all extracts was read at $340 \mathrm{~nm}$ for different concentrations and the percentage of the total anti-collagenase potential of ethyl acetate, n-butanol, and aqueous extracts of $C$. sativus was calculated. The ethyl acetate, n-butanol, and aqueous extracts of C. sativus at $100 \mu \mathrm{g} / \mathrm{ml}$ exhibited a maximum total Collagenase inhibition (Fig. 4) of 69.06, 67.12, and $65.09 \mu \mathrm{g} / \mathrm{ml}$, respectively. The $\mathrm{IC}_{50}$ value of the ethyl acetate $(45.79 \mu \mathrm{g} / \mathrm{ml})$, n-butanol $(50.59 \mu \mathrm{g} / \mathrm{ml})$, and aqueous $(56.88 \mu \mathrm{g} / \mathrm{ml})$ extracts of $C$. sativus was found to be significant $(\mathrm{p}<0.04)$ in comparison to standard catechin having the $\mathrm{IC}_{50}$ value $18.21 \mu \mathrm{g} / \mathrm{ml}$.

\section{Tyrosinase inhibitory activity}

The absorbance of all extracts was read at $492 \mathrm{~nm}$ for different concentrations and the percentage of the total anti-tyrosinase potential of ethyl acetate, n-butanol, and aqueous extracts of $C$. sativus was calculated. The ethyl acetate, $\mathrm{n}$-butanol, and aqueous extracts of $C$. sativus at $100 \mu \mathrm{g} / \mathrm{ml}$ exhibited a maximum total tyrosinase inhibition (Fig. 5) of $77.21,87.03$, and $79.01 \mu \mathrm{g} / \mathrm{ml}$. The $\mathrm{IC}_{50}$ value of the ethyl acetate (24.46 $\mu \mathrm{g} / \mathrm{ml})$, n-butanol $99.68 \mu \mathrm{g} / \mathrm{ml})$, and aqueous $(40.09 \mu \mathrm{g} / \mathrm{ml})$ extracts of $C$. sativus was found to be significant $(\mathrm{p}<0.04)$ as compared to standard quercetin having the $\mathrm{IC}_{50}$ value $18.27 \mu \mathrm{g} / \mathrm{ml}$.

$\mathrm{IC}_{50}$ of $C$. sativus extracts for antioxidant assay and all enzymatic assays are shown in Table 2 .

\section{DISCUSSION}

Photoaging is mainly stimulated by the excessive exposure of skin to UV radiations, which causes the release of ROS, thereby rendering

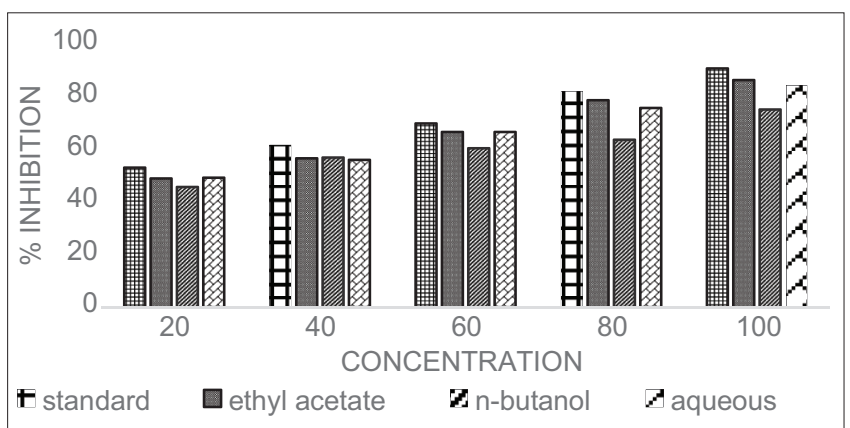

Fig. 4: Collagenase inhibitory potential of Cucumis sativus extracts to compare with catechin. All values were found to be significant $(\mathbf{p}<0.04)$

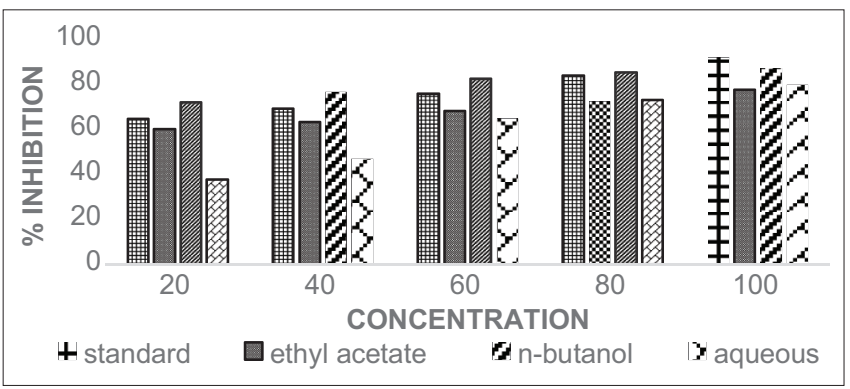

Fig. 5: Tyrosinase inhibitory potential of Cucumis sativus extracts to compare with quercetin. All values were found to be significant $(\mathrm{p}<0.04)$ 
Table 2: $\mathrm{IC}_{50}$ of extracts of Cucumis sativus fruit in antioxidant and other enzymatic assays

\begin{tabular}{llllll}
\hline S. No & Assay & $\mathbf{I C}_{\mathbf{5 0}}(\boldsymbol{\mu g} / \mathbf{m l})$ & & & \\
\cline { 3 - 6 } & & Standard & Ethyl acetate extract & N-butanol extract & Aqueous extract \\
\hline 1. & Antioxidant assay & 24.57 & 358.04 & 294.64 & 122.67 \\
2. & Hyaluronidase inhibition assay & 14.57 & 59.54 & 377.28 & 75.84 \\
3. & Elastase inhibition assay & 1.84 & 52.76 & 42.16 & 66.08 \\
4. & MMP-1/collagenase inhibition assay & 18.21 & 45.79 & 50.59 & 56.88 \\
5. & Tyrosinase inhibition assay & 18.27 & 24.46 & 99.68 & 40.09 \\
\hline IC & & & &
\end{tabular}

severe damage to proteins, lipids, and DNA. C. sativus flesh mainly consists of water, ascorbic acid (Vitamin C), gallic acid, caffeic acid, flavonoids, phenolic compounds, etc., and is known to be used in many skincare products to reduce the signs of skin aging and relieve skin irritations [22]. In the present study, the anti-aging and anti-wrinkle potential of $C$. sativus fruit was studied through in vitro estimation of antioxidant, anti-hyaluronidase, anti-elastase, anti-collagenase/antiMMP, and anti-tyrosinase activity. The aqueous extract of $C$. sativus was fractionated into ethyl acetate and n-butanol fraction to correlate the possible constituents responsible for the observed activities. The maximum antioxidant activity was exhibited by the aqueous fraction as it is rich in ascorbic acid, cucurbitacin a, b, c, and $96 \%$ water. The ethyl acetate fraction contains organic compound such as citric acid, malic acid, gallic acid, caffeic acid, and $\alpha$-linoleic acid and may be responsible for the anti-hyaluronidase, anti-collagenase/anti-MMP, and anti-tyrosinase activity. The elastase inhibition was maximum shown by the n-butanol fraction. This may be attributed to the presence of phenolic compound such as p-hydroxybenzoic acid, hydroxycinnamic acid, flavones, $\beta$ - carotene, flavanols, squalene, and $\beta$ - sitosterol. The presence of carotenoids, phenolic flavonoids, tannins, polyphenols, and lycopene was confirmed by the various phytochemical screening studies carried out by different researchers [23-25]. The main acids found are citric and malic acids. Phenolic compounds present are p-hydroxybenzoic acid, hydroxycinnamic acid, flavones, and flavonols. Cucumber is rich in Vitamin C and Vitamin B [26].

\section{CONCLUSION}

From the above results, it was concluded that the lyophilized extracts of $C$. sativus are potent inhibitors of the hyaluronidase, elastase, MMP$1 /$ collagenase, and tyrosinase enzymes. It also has potential to inhibit the free radicals. Therefore, it can be accomplished that $C$. sativus plays important role in the skincare products and can be investigated further for its use in cosmetics industries.

\section{AUTHORS' CONTRIBUTIONS}

1. Dr. Chanchal Garg: Designed the project and performed the analytical part of the research

2. Mr. Ravinder: Prepared the plant extract

3. Prof. Munish Garg: Provide supervision and guidance in this research work.

\section{CONFLICTS OF INTEREST}

The authors declare that they have no conflicts of interest.

\section{FUNDING SUPPORT}

None.

\section{REFERENCES}

1. Markrantonaki E, Zouboulis CC. Molecular mechanisms of skin aging: State of the art. Ann N Y Acad Sci 2007;1119:40-50.

2. Nema NK, Maity M, Sarkar BK, Mukherjee PK. Matrix metalloproteinase, hyaluronidase and elastase inhibitory potential of standardized extract of Centella asiatica. Pharm Biol 2013;51:1182-7.

3. Widowati W, Fauziah N, Herdiman H, Afni M, Afifah E, Sari H, et al.
Antioxidant and anti-aging assays of Oryza sativa extracts, vanillin and coumaric acid. J Nat Remedies 2016;16:2320-58.

4. Ndlovu G, Fouche G, Tselanyane M, Cordier W, Steenkamp V. In vitro determination of the anti-aging potential of four Southern African medicinal plants. BMC Complement Alter Med 2013;13:304.

5. Ganceviciene R, Liakou AI, Theodoridis A, Makrantonaki E, Zouboulis CC. Skin anti-aging strategies. Dermato Endocrinol 2012;4:308-19.

6. Manuskiatti W, Maibach HI. Hyaluronic acid and skin: Wound healing and aging. Int J Dermatol 1996;35: 2397-404.

7. Papakonstantinou E, Roth M, Karakiulakis G. Hyaluronic acid: A key molecule in skin aging. Dermato Endocrinol 2012;4:253-8.

8. Briganti S, Camera E, Picardo M. Chemical and instrumental approaches to treat hyperpigmentation. Pigm Cell Res 2003;16:101-10.

9. Sturm RA, Teasdale RD, Box NF. Human pigmentation genes: Identification, structure and consequences of polymorphic variation. Gene 2001;277:49-62.

10. Sahu T, Sahu J. Cucumis sativus (cucumber): A review on its pharmacological activity. J Appl Pharm Res 2015;3:4-9.

11. Patri G, Silano V, Anton R. Plants in Cosmetics. Strasbourg: Council of Europe Publishing; 2002.

12. Warrier PK. Indian Medicinal Plants: A Compendium of 500 Species. Chennai: Orient Longman; 1994.

13. Shah P, Dhande S, Joshi Y, Kadam V. A review on Cucumis sativus (cucumber). Res J Pharm Phytochem 2013;5:49-53.

14. Braca A, Tommasi ND, Bari LD, Pizza C, Politi M, Morelli I. Antioxidant principles from Bauhinia terapotensis. J Nat Prod 2001;64:892-5.

15. Lee BC, Lee SY, Lee HJ, Sim GS, Kim JH, Kim J. Anti-oxidative and photo protective effects of coumarins isolated from Fraxinus chinensis. Arch Dermatol Res 2007;30:1293-301.

16. Kim YJ, Uyama H, Kobayashi S. Inhibition effects of (+)-catechinaldehyde polycondensates on proteinases causing proteolytic degradation of extracellular matrix. Biochem Biophys Res Commun 2004;320:256-61.

17. Pientaweeratch S, Panapisa V, Tansirikongkol Y. Antioxidant, anticollagenase and anti-elastase activities of Phyllanthus emblica, Manilkara zapota and silymarin: An in vitro comparative study for antiaging applications. Pharm Biol 2016;54:1865-72.

18. Hsu C, Chang C, Lu H, Chung Y. Inhibitory effects of the water extracts of Lavandula sp. on mushroom tyrosinase activity. Food Chem 2007;105:1099-105.

19. Wang BS, Chang LW, Wu HC, Huang SL, Chu HL, Huang MH. Antioxidant and antityrosinase activity of aqueous extracts of green asparagus. Food Chem 2011;127:141-6.

20. Jiménez M, Chazarra S, Escribano J, Cabanes J, García-Carmona F. Competitive inhibition of mushroom tyrosinase by 4 -substituted benzaldehydes. J Agric Food Chem 2001;49:4060-3.

21. Kubo I, Kinst-Hori I. Tyrosinase inhibitory activity of the olive oil flavor compound. J Agric Food Chem 1999;47:4574-8.

22. Sumathi T, Ponnuswami V, Senthamizh BS. Anatomical changes of cucumber (Cucumis sativus L.) leaves and roots as influenced by shade vand fertigation. Res J Agric Biol Sci 2008;4:630-8.

23. Mallik J, Akhter R. Phytochemical screening and in vitro evaluation of reducing power, cytotoxicity and anti-fungal activities of ethanol extracts of Cucumis sativus. Int J Pharm Biol Sci Arch 2012;3:555-60.

24. Tiwari, P, Kumar B, Kaur M, Kaur G, Kaur H. Phytochemical screening and extraction: A review. Int Pharm Sci 2011;1:98-106.

25. Belitz HD, Grosch W. Química de los Alimentos. Zaragoza: Editorial Acribia S.A; 1997. p. 825-60.

26. Musmade AM, Desai UT. Cucumber and melon. In: Handbook of Vegetable Science and Technology: Production, Composition, Storage, and Processing. New York: Marcel Dekker, Inc.; 1998. p. 245-72. 